Check for updates

The BMJ

kabbasi@bmi.com Follow Kamran on Twitter@KamranAbbasi Cite this as: BMJ 2021;375:n2885 http://dx.doi.org/10.1136/bmj.n2885 Published: 25 November 2021

\section{The dangers in policy and practice of following the consensus}

\section{Kamran Abbasi executive editor}

What is the consensus? How is it that women carry out 11 billion hours a day of unpaid work, yet society pays little heed to their wellbeing

(doi:10.1136/bmj.n1972)? ${ }^{1}$ What is the explanation for the unexpected differences in life expectancy between ethnic groups (doi:10.1136/bmj-2021-068537)? ${ }^{2}$ Why is it so hard to tackle the racism that health professionals from ethnic minority groups experience daily and persistently (doi:10.1136/bmj.n2832)? ${ }^{3}$ What is the role of health professionals in preventing and tackling abuse of elderly people (doi:10.1136/bmj.n2828)? ${ }^{4}$

Does consensus even matter when it's the evidence that should matter? Take the evidence on covid vaccines, for example. However sceptical you might be about the efficacy trials and their lack of transparency, the real world research, a good deal of which The BMJ has published in the past 12 months, shows clear benefit of vaccination (doi:10.1136/bmj.n2034, doi:10.1136/bmj.n1088, doi:10.1136/bmj.n1943, doi:10.1136/bmj.n2015). . $^{-8}$ The true picture of adverse effects from the vaccines is yet to emerge, of course, and relies on thorough postmarketing surveillance.

Yet many guidelines are based on consensus and sold to us in such a way that we might assume the authority of the assembled experts to be greater than the accumulated evidence. New research analysing US guidelines in cardiology and oncology instead finds that consensus based guidelines are more likely to make discordant and inappropriate recommendations relative to the evidence base (doi:10.1136/BMJ-2021-066045, doi:10.1136/bmj.n2833). $9{ }^{90}$ Evidence based guidelines are also prone to similar errors, albeit to a lesser degree. The overall message, then, is a damning verdict on the guidelines industry and the risk that it poses to patient safety.

Of covid-19 vaccines, mRNA vaccines are the most controversial, by any consensus. Messenger RNA was discovered in the 1960s, and, through incremental advances achieved by many different international scientists, it was ripe for rapid exploitation when SARS-CoV-2 began to disrupt lives and livelihoods. The mRNA covid-19 vaccines continue to attract suspicion about associated risks; they are marketed aggressively and earn vast profits for their manufacturers.

A new study underlines the concern about the waning immunity of Pfizer's mRNA vaccine (doi:10.1136/BMJ2021-067873), ${ }^{11}$ while an outcry grows about the unwillingness of rich companies, such as Pfizer and Moderna, to share technology and manufacturing knowhow with poor countries. But the hope beneath the hype and hesitancy may be genuine, of a technology that offers the potential to cure or prevent a wide range of conditions from malaria to cancer (doi:10.1136/bmj.n2744). ${ }^{12}$

China's Sinovac vaccine is of more traditional "inactivated" design. Less reassuring efficacy data may be one explanation why China is sticking with "zero tolerance" public health measures despite already having vaccinated over $75 \%$ of its population. Strict measures have left China's population with little natural immunity, and exposure to the delta variant is a risk unless population immunity is higher (doi:10.1136/bmj.n2756). ${ }^{13}$

By consensus, the UK's policy is closer to "full tolerance" of covid, much to the dismay of professionals concerned for children's welfare (doi:10.1136/bmj.n2826, doi:10.1136/bmj.n2844), ${ }^{1415}$ worried about high death rates

(doi:10.1136/bmj.n2843), ${ }^{16}$ enraged by government complacency and corruption (doi:10.1136/bmj.n2773, doi:10.1136/bmj.n2825), ${ }^{1718}$ and disturbed by vaccine hesitancy in pregnant women

(doi:10.1136/bmj.n2862). ${ }^{19}$ Whether you are minded to believe these consensus views or not, you might consider one piece of evidence related to the knock-on effects of the toll that covid has placed on acute care: overcrowding and delays in emergency departments led to 4519 excess deaths in England over the past 12 months (doi:10.1136/bmj.n2835). ${ }^{20}$

It's an "alarming” statistic that will certainly interest Independent SAGE, an expert group committed to evidence based policy making, members of which write to explain why we were wrong to call them "rebel scientists" (doi:10.1136/bmj.n2850, doi:10.1136/bmj.n2504). ${ }^{21} 22$ On the other hand, you might say that rebelling against a harmful consensus is something to be proud of.

Seedat S, Rondon M. Women's wellbeing and the burden of unpaid work BM/2021;374:n1972. doi: 10.1136/bmj.n1972 pmid: 34465574

2 Ali R, Raleigh V, Majeed A, Khunti K. Life expectancy by ethnic group in England. BM/2021;375:e068537.

doi: 10.1136/bmj-2021-068537 pmid: 34753743

Kar P. Partha Kar: Holding up a mirror to racism in the NHS. BMJ 2021;375:n2832. doi: 10.1136/bmj.n2832 pmid: 34799369

4 Stephens C, Mays N, Issa R, Perkins L, Scott R. Elder abuse in the UK: out of the shadows and on to the agenda. $B M$ J 2021;375:n2828doi: 10.1136/bmj.n2828

5 Hungerford D, Cunliffe NA. Real world effectiveness of covid-19 vaccines BM/2021;374:n2034doi: 10.1136/bmi.n2034.

6 Lopez Bernal J, Andrews N, Gower C, etal. Effectiveness of the Pfizer-BioNTech and Oxford-AstraZeneca vaccines on covid-19 related symptoms, hospital admissions, and mortality in older adults in England: test negative case-control study. BMJ2021;373:n1088. doi: 10.1136/bmj.n1088 pmid: 33985964

7 Chung H, He S, Nasreen S, etalCanadian Immunization Research Network (CIRN) Provincial Collaborative Network (PCN) Investigators. Effectiveness of BNT162b2 and mRNA-1273 covid-19 vaccines against symptomatic SARS-CoV-2 infection and severe covid-19 outcomes in Ontario, Canada: test negative design study. BM/2021;374:n1943. doi: 10.1136/bmj.n1943 pmid: 34417165 
8 Ranzani OT, Hitchings MDT, Dorion M, etal. Effectiveness of the CoronaVac vaccine in older adults during a gamma variant associated epidemic of covid-19 in Brazil: test negative case-control study. BMJ2021;374:n2015. doi: 10.1136/bmj.n2015 pmid: 34417194

9 Yao L, Ahmed MM, Guyatt GH, etal. Discordant and inappropriate discordant recommendations in consensus and evidence based guidelines: empirical analysis. BMJ2021;375:e66045.

10 Yao L, Guyatt GH, Djulbegovic B. Can we trust strong recommendations based on low quality evidence?BM/2021;375:n2833

11 Israel A, Merzon E, Schaffer AA, etal. Elapsed time since BNT162b2 vaccine and risk of SARS-CoV-2 infection: test negative design study. BMJ 2021;375:e067873doi: 10.1136/bmj-2021-067873.

12 Extance A. mRNA vaccines: hope beneath the hype. BMJ2021;375:n2744doi: 10.1136/bmj.n2744.

13 Silver A. Covid-19: Why China is sticking to "zero tolerance" public health measures. BMJ 2021;375:n2756.

14 Wise J. Headlines play down the gravity of covid-19 in children. BMJ2021;375:n2826.

15 Oliver D. David Oliver: Dismissing unwell people to argue for pandemic freedoms is abhorrent and unrealistic. BMJ 2021;375:n2844doi: 10.1136/bmj.n2844.

16 Altmann D, Boyton R. Covid-19 caseload in the UK-assessments and mitigations. BMJ 2021;375:n2843. doi: 10.1136/bmj.n2843 pmid: 34794957

17 Patterson L. Encouraging covid vaccine uptake and safe behaviours-an uphill struggle against government complacency. BMJ 2021;375:n2773. doi: 10.1136/bmj.n2773 pmid: 34772667

18 Wise J. Covid-19: Ten Conservative MPs and peers referred companies to "VIP lane" that won f1.6bn of PPE contracts. BMJ2021;375:n2825. doi: 10.1136/bmj.n2825 pmid: 34789466

19 lacobucci G. Covid-19 and pregnancy: vaccine hesitancy and how to overcome it. BMJ 2021;375:n2862. doi: 10.1136/bmi.n2862 pmid: 34810161

20 lacobucci G. Overcrowding and long delays in A\&E caused over 4000 deaths last year in England, analysis shows. BM/2021;375:n2835. doi: 10.1136/bmj.n2835 pmid: 34794954

21 Pillay DIndependent Scientific Advisory Group for Emergencies. Independent SAGE replies to The BMJ. BMJ2021;375:n2850. doi: 10.1136/bmi.n2850 pmid: 34810157

22 Clarke L. Covid-19's rebel scientists: has iSAGE been a success?BM] 2021:375:n2504doi: 10.1136/bmi.n2504. 